\title{
Foundational Documents
}

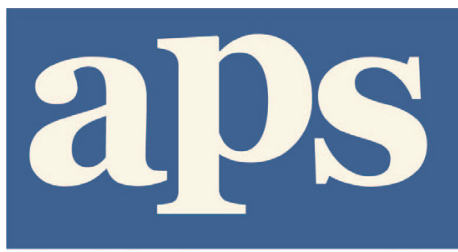

National Association of Friendship Centres (NAFC) Letters Patent

\section{National Association of Friendship Centres (NAFC) \\ Provided by Jeff Cyr, Executive Director}

aboriginal policy studies Vol. 1, no. 3, 2011, pp. 103-115

This article can be found at:

http://ejournals.library.ualberta.ca/index.php/aps/article/view/12562

ISSN: $1923-3299$

Article DOI: http://dx.doi.org/10.5663/aps.vli3.12562

aboriginal policy studies is an online, peer-reviewed and multidisciplinary journal that publishes original, scholarly, and policy-relevant research on issues relevant to Métis, nonstatus Indians and urban Aboriginal people in Canada. For more information, please contact us at apsjournal@ualberta.ca or visit our website at www.ualberta.ca/nativestudies/ aps/ or http://ejournals.library.ualberta.ca/index.php/aps/. 


\section{Foundational Documents}

\section{National Association of Friendship Centres (NAFC) History and Letters Patent}

Provided by Jeff Cyr, Executive Director

National Association of Friendship Centres (NAFC)

\section{Introduction}

The National Association of Friendship Centres (NAFC) is a national Aboriginal not-for-profit organization representing the concerns of 125 cultural and community development organizations across Canada. We are celebrating our $40^{\text {th }}$ year in 2011 and are proud of our history. As Canada's largest infrastructure of Aboriginal service delivery providers, the National Association of Friendship Centres advocates on behalf of the diverse and changing needs of urban First Nation, Métis and Inuit peoples living in large and small urban settings throughout Canada.

The mission statement of the NAFC is:

To improve the quality of life for Aboriginal Peoples in an urban environment by supporting self-determined activities which encourage equal access to, and participation in, Canadian society, and which respects and strengthens the increasing emphasis on Aboriginal cultural distinctiveness.

Friendship Centres deliver a wide spectrum of programs and services to Aboriginal peoples living in diverse and increasing urban Aboriginal communities in towns and cities across the country. Friendship Centres represent a community-based and -directed Aboriginal institution serving the interests of urban Aboriginal Peoples in the areas of social, cultural, recreational, economic and community development. In any one year, Friendship Centres across Canada serve more than one million client contacts through over one thousand programs. All of our programs are provided 'status-blind' - that is, without consideration if a person is a status Indian, non-status Indian, Métis or Inuit.

\section{History}

The origin of today's Friendship Centre began in the mid-1950s as the number of Aboriginal people moving into larger urban areas increased. Aboriginal agencies emerged out of a clear need for specialized services to aid Aboriginal newcomers to the city. These agencies would provide referrals and offer counselling on matters of employment, housing, education, health and liaison with other community organizations. As the demand for services by urban and migrating First Nations, Inuit and Métis people increased so did the number of Friendship Centres. The nature of programming and services and critical need for more funding was quickly amplified. 
In the late sixties, Friendship Centres began to organize into Provincial / Territorial Association's (PTA's). In 1969, a steering committee of Friendship Centres was struck to examine the feasibility of establishing a national body to represent the growing number of Friendship Centres.

Until 1972, Friendship Centres were dependant, to a large degree, on individual volunteers and their ability to raise operating funds though various fund raising events, private donations and small grants from foundations and provincial and federal governments. Centres also began to evolve from the provision of referrals to the "front line" delivery of social services.

In 1972 the government of Canada formally recognized the viability of Friendship Centres and implemented the Migrating Native Peoples Program (MNPP). In 1976, the government conducted an evaluation of the MNPP which revealed the vital role that Friendship Centres played in the communities they served and the wide base of the community support they had established. Friendship Centres were also able to utilize limited resources in a creative and flexible manner while remaining accountable to their communities. In spite of the many obstacles, Friendship Centres have continued to expand the programs and services offered to urban Aboriginal People.

In 1983, the NAFC and the Department of the Secretary of State (DSOS) successfully negotiated the evolution of the MNPP to an enriched Native Friendship Centre Program (NFCP). This program, with a five year mandate, formally recognized "Friendship Centres as legitimate urban Native institutions responding to the needs of Native people." In 1988, the NFCP became the Aboriginal Friendship Centres Program (AFCP), which secured the status of permanent funding from DSOS.

In 1988, the federal government established a permanent program-the Aboriginal Friendship Centre Program (AFCP). Because of the quality of services provided and the vital role they played in the communities they served, the Friendship Centres gained an increasingly positive reputation with the government as legitimate urban Native institutions responding to the needs of Aboriginal people.

The funding relationship fundamentally changed in 1996, when the administrative responsibility for the AFCP was transferred from the Department of Canadian Heritage to the National Association of Friendship Centres (NAFC). This new agreement meant that all operational funding for the AFCP would be administered by the NAFC to the local Friendship Centres and the PTAs. This devolution signified a new era in Aboriginal/ Government relations and, to this day, suggests a unique relationship with the Government of Canada. It notably demonstrated a commitment on behalf of the government to increase the capacity and sustainability of Aboriginal organizations.

Today, over half of a century after the initial development of Friendship Centres in Canada, the Friendship Centre Movement has expanded and continues to offer the same essential programs and services to urban Aboriginal people across Canada. A total of 117 Friendship Centres are members of the National Association of Friendship Centres. 
(NAFC) History and Letters Patent

The Friendship Centre Movement is unique in the broad spectrum of specialized services it provides to urban Aboriginal people across Canada. The provision of services currently offered at Friendship Centres is specialized and may include areas such as: Culture, Family, Youth, Sports and Recreation, Language, Justice, Housing, Health, Education, Employment, Economic Development and a variety of miscellaneous projects ranging from social activities to community building initiatives and special events.

\section{Origins of The Friendship Centre Movement}

1951: Friendship Centre established in Toronto, ON - North American Indian Club.

1952: Friendship Centre established in Vancouver, BC - Coqualeetza Fellowship Club.

1959: Friendship Centre established in Winnipeg, MB - Indian and Métis Friendship Centre.

1968: 26 Friendship Centres across Canada

1969: Friendship Steering Committee established to examine the feasibility of a national body to represent Friendship Centres.

1972: National Association of Friendship Centres is incorporated. Government of Canada implements the Migrating Native Peoples Programme (MNPP). 43 Friendship Centres across Canada.

1983: The NAFC and the Department of the Secretary of State (DSOS) successfully negotiated the evolution of the MNPP to an enriched Native Friendship Centre Program (NFCP). 80 Friendship Centres across Canada

1988: The NFCP became the Aboriginal Friendship Centre Program (AFCP), which secured the status of the permanent funding from DSOS.

1996: The Department of Canadian Heritage (PCH), formerly DSOS, transfers administrative responsibility of the AFCP to the NAFC. 114 Friendship Centres across Canada.

2001: The NAFC renews AFCP transfer agreement between PCH and NAFC.

2010: 117 Friendship Centres across Canada. 
CANADA

LETTERS PATENT

WHEREAS an application has been filed to incorporate a corporation under the name

\section{NATIONAL ASSOCIATION OF FRIENDSHIP CENTRES}

THEREFORE the Minister of Consumer and Corporate Affairs, by virtue of the powers vested in him by the Canada Corporations Act, constitutes the applicants and such persons as may hereafter become members in the corporation hereby created, a body corporate and politic in accordance with the provisions of the said Act. A copy of the said application is attached hereto and forms part hereof.

GIVEN AT OTTAWA, under my seal of office, this twenty-third day of April, one thousand nine hundred and seventy-five.

[signed by]

For the Minister of Consumer and Corporate Affairs.

RECORDED 25 $5^{\text {th }}$ April, 1975

Film 375 Document 347

[signed by]

Deputy Registrar General of Canada

\section{APPLICATION FOR INCORPORATION OF A CORPORATION WITHOUT SHARE CAPITAL UNDER PART II OF THE CANADA CORPORATIONS ACT \\ TO THE MINISTER OF CONSUMER AND CORPORATE AFFAIRS OF CANADA}

The undersigned hereby apply to the Minister of Consumer and Corporate Affairs for the grant of a charter by letters patent under the provisions of Part II of the Canada Corporations Act constituting the undersigned, and such other persons as hereafter become shareholders in the company thereby created, a body corporate and politic under the name of:

\section{NATIONAL ASSOCIATION OF FRIENDSHIP CENTRES.}

The undersigned have satisfied themselves and are assured that the proposed name under which incorporation is sought is not the same or similar to the name under which any other company, society, association or firm, in existence is carrying on business in Canada or any province thereof or so nearly resembles the same as to be calculated to deceive and that it is not a name which is otherwise on public grounds objectionable. 
II

The applicants are individuals of the full age of twenty-one (21) years with power under law to contract. The name, the place of residence and the calling of each of the applicants who are to be the first directors of the corporation as follows:

\section{OCCUPATION}

Full time Executive Director

Mr. Xavier Michon

Thunder Bay Indian Friendship Centre

401 N. Cumberland Street

THUNDER BAY, Ontario

Phone: (807) 344-0706

Full time Executive Director

Mrs. Marge Cantryn

Vancouver Indian Friendship Centre

1855 Vine Street

VANCOUVER, B.C.

Phone: (604) 736-8944

Full time Executive Director

Mr. Rick Marshall

Brandon Indian \& Metis Friendship Centre

836 Lorne Street

BRANDON, Manitoba

Phone: (204) 727-4368 
The objectives of the Corporation are:

(a) To unite friendship centres and their provincial associations into a unified whole authorized, upon request, to negotiate on behalf of its constituent members all levels of governments.

(b) To provide a central body to facilitate communications between the exchange of ideas among the constituent members.

(c) To co-operate with provincial associations in the establishment of new friendship centres.

(d) To act as a central public relations agency authorized to represent all constituent members.

(e) To provide support on a national level to its constituent members involved in local issues having national implications.

(f) To promote self-recognition and recognition by the community at large of the identity, culture and heritage of native peoples.

(g) To promote and encourage the involvement of native peoples in the activity of their local centres.

(h) To maintain liaison with representatives of native people and all other organizations involved with native people.

(i) To remain non-partisan in religious and political matters.

(j) To encourage the assistance of service agencies, voluntary organizations, private industry and all levels of government in the advancing and maintaining the wellbeing of the constituent members and the native peoples of Canada.

IV

The operations of the Corporation may be carried on throughout Canada and elsewhere.

$\mathrm{V}$

The place within Canada where the head office of the Company is to be situated is:

In the City of Ottawa, in the Regional Municipality of Ottawa-Carleton and Province of Ontario.

VI

It is specially provided that in the event of dissolution or the winding up of the Corporation all its remaining assets after payment of its liabilities shall be distributed to one or more recognized charitable organizations in Canada. 
(NAFC) History and Letters Patent

VII

In accordance with Section 65 of the Canada Corporations Act, it is provided that, when authorized by by-law, duly passed by the directions and sanctioned by at least twothirds of the votes cast at a special meeting of the shareholders duly called for considering the by-law, the directors of the Corporation may from time to time:

(a) borrow money upon the credit of the Corporation;

(b) limit or increase the amount to be borrowed;

(c) issue debentures or other securities of the Corporation;

(d) pledge or sell such debentures or other securities for such sums and at such prices as may be deemed expedient; and

(e) secure any such debentures, or other securities, or any other present or future borrowing or liability of the Corporation, by mortgage, hypothec, charge or pledge of all or any currently owned or subsequently acquired real and personal movable and immovable, property of the Corporation, and the undertaking of rights of the Corporation.

Any such by-law may provide for the delegation of such powers by the directors to such officers or directors of the Corporation to such extent and in such manner as may be set out in the by-law.

Nothing herein limits or restricts the borrowing of money by the Corporation on bills of exchange or promissory notes made, drawn, accepted or endorsed by or on behalf of the Corporation.

\section{VIII}

The By-laws of the Corporation shall be those filed with the Application for Letters Patent until repealed, amended, altered or added to.

IX

The Corporation is to carry on its operations without pecuniary gain to its members, and any profits or other accretions to the Corporation are to be used in promoting its objects.

DATED at the City of Ottawa, in the Province of Ontario this $21^{\text {st }}$ day of April, 1975.

\section{WITNESS}

[signed by]

Xavier Michon

Marge Cantryn

Rick Marshall 
CANADA

SUPPLEMENTARY LETTERS PATENT

issued to

\section{NATIONAL ASSOCIATION OF FRIENDSHIP CENTRES}

The Minister of Consumer and Corporate Affairs by virtue of the powers vested in him by the Canada Corporations Act, does hereby amend and vary the provisions of the letters patent incorporating the Corporation as provided in Resolutions \#1-8 of the said Corporation, a copy of which is annexed hereto to form part of these presents.

Date of Supplementary Letters Patent

April 17, 1986

GIVEN under the seal of office of the Minister of Consumer for the Minister of Consumer and Corporate Affairs.

[signed by]

For the Minister of Consumer and Corporate Affairs

RECORDED April 22, 1986

Film 549 Document 64

[signed by]

Deputy Registrar General of Canada

Resolutions Respecting Change of Objects and Powers

THE NATIONAL ASSOCIATION OF FRIENDSHIP CENTRES

Resolutions \#1-8

Being resolutions respecting change of objects and powers BE IT ENACTED and it is hereby enacted as resolutions 1-8 of the National Association of Friendship Centres that:

1. The Corporation be and is hereby authorized to make application to the Honourable Michel Cote the Minister of Consumer and Corporate Affairs for Supplementary Letters Patent changing the objects and powers of the Corporation as follows: 
(NAFC) History and Letters Patent

RESOLUTION \#1 Jerome Berthelette/Viola Thomas

BE IT MOVED THAT Paragraph (b) of the Objectives of the Corporation be amended by adding the word "and", so it reads as follows:

(b) To provide a central body to facilitate communications between and the exchange of ideas among the constituent members.

\section{CARRIED}

RESOLUTION \#2 Viola Thomas/Jerome Berthelette

BE IT MOVED THAT, Paragraph (c) of the Objectives of the Corporation be amended by adding the words "Friendship Centres", so it reads as follows:

(c) To cooperate with Friendship Centres and Provincial/Territorial Associations in the establishment of new Friendship Centres.

\section{CARRIED}

RESOLUTION \#3 Jerome Berthelette /Viola Thomas

BE IT MOVED THAT, Paragraph (d) of the Objectives of the Corporation be amended by adding the words "upon request", so it reads as follows:

(d) To act as a central public relations agency authorized upon request to represent all constituent members.

\section{CARRIED}

RESOLUTION \#4 Viola Thomas/Jerome Berthelette

BE IT MOVED THAT, Paragraph (e) of the Objectives of the Corporation be amended to add the words "at the" and "and to provide such other support at the national level as requested by its constituent members", so it reads as follows:

(e) To provide support at the national level to its constituent members involved in local issues having national implications and to provide such other support at the national level as requested by its constituent members.

\section{CARRIED}


RESOLUTION \#5 Jerome Berthelette/Viola Thomas

BE IT MOVED THAT, Paragraph (j) of the Objectives of the Corporation be amended to add the word "of" so it reads as follows:

(j) To encourage the assistance of service agencies, voluntary organizations, private industry and all levels of government in the advancing and maintaining of the wellbeing of the constituent members and the native peoples of Canada.

\section{CARRIED}

RESOLUTION \#6 Viola Thomas/Jerome Berthelette

BE IT MOVED THAT, Paragraph VI of the Letters patent be amended by adding the words "having cognate or similar objects", so it reads as follows:

VI It is specially provided that in the event of dissolution or the winding up of the Corporation all its remaining assets after payment of its liabilities shall be distributed to one or more recognized charitable organizations in Canada, having cognate or similar objects.

\section{CARRIED}

RESOLUTION \#7 Jerome Berthelette/Viola Thomas

BE IT MOVED THAT, Paragraph VII of the letters patent be amended by deleting the word "shareholders" and substituting therefore the word "members", so it reads as follows:

IV In accordance with Section 65 of the Canada Corporations Act, it is provided that, when authorized by by-law, duly passed by the Directors and sanctioned by at least two-third of the votes east at a special meeting of the members duly called for considering the by-law, the Directors of the Corporation may from time to time:

\section{CARRIED}

RESOLUTION \#8 Viola Thomas/Jerome Berthelette

BE IT MOVED THAT, Paragraph VII (d) be amended by deleting paragraph (d) and substituting therefore the following two paragraphs:

(d) pledge or sell such debentures or other securities for such sums and at such prices as may be deemed expedient; 
(e) secure any such debentures or other securities, or any other present or future borrowing or liability of the Corporation, by mortgage, hypothec, charge or pledge of all or any currently owned or subsequently acquired real or personal movable and immovable, property of the Corporation, and the undertaking rights of the Corporation.

\section{CARRIED}

2. The directors be and are hereby authorized to do, sign and execute all things, deeds and documents necessary or desirable for the due carrying out of the foregoing.

DATED at [Monday] this [3] day of [March 1986].

[signed by]

President

Secretary 


\title{
CANADA \\ SUPPLEMENTARY LETTERS PATENT \\ issued to \\ NATIONAL ASSOCIATION OF FRIENDSHIP CENTRES
}

The Minister of Consumer and Corporate Affairs by virtue of the powers vested in him by the Canada Corporations Act, does hereby extend the objects of NATIONAL ASSOCIATION FRIENDSHIP CENTRES as provided in a BY-LAW of the said Corporation, a copy of which is annexed hereto to form part of these presents.

Date of Supplementary Letters Patent - August 17, 1989

GIVEN under: the seal of office of the Minister of Consumer and Corporate Affairs.

[signed by]

For the Minister of Consumer and Corporate Affairs

RECORDED 30th August, 1989

Film 623 Document 99

[signed by]

Deputy Registrar General of Canada

\author{
By-law respecting Exension of Objects \\ NATIONAL ASSOCIATION OF FRIENDSHIP CENTRES \\ (NAME of CORPORATION)
}

by-law No.

Being a by-law respecting extension of objects BE IT ENACTED and it is hereby enacted as a By-law of the National Association of Friendship Centres therein called the Corporation) that:

1. The Corporation be and is hereby authorized to make application to the Honourable the Minister of Consumer and Corporate Affairs for Supplementary Letters Patent extending the objects of the Corporation by adding thereto the following clauses:

To provide a central body to facilitate communications between and the exchange of ideas among the constituent members in our Aboriginal languages, as well as the English and French languages. 
2. The directors be and are hereby authorized to do, sign and execute all things, deeds and documents necessary or desirable for the due carrying out of the foregoing.

DATED at Ottawa this [14 $\left.4^{\text {th }}\right]$ day of [August], 1989

[signed by]

President

Secretary 